NBER WORKING PAPER SERIES

\title{
DEMAND FOR ILLICIT DRUGS BY PREGNANT WOMEN
}

\author{
Hope Corman \\ Kelly Noonan \\ Nancy E. Reichman \\ Dhaval Dave \\ Working Paper 10688 \\ http://www.nber.org/papers/w10688
}

\author{
NATIONAL BUREAU OF ECONOMIC RESEARCH \\ 1050 Massachusetts Avenue \\ Cambridge, MA 02138
}

August 2004

This paper was prepared for the "Economics of Substance Use-Individual Behavior, Social Interactions, Markets, and Politics" symposium in Lund, Sweden, August 13-14. The research and data collection were funded by Grants \#R01-HD-35301 and \#R01-HD-45630 from the National Institute of Child Health and Human Development. We are grateful for the valuable assistance of Ofira Schwartz, Jennifer Borkowski, Brian Tokar, Andrew Shore, and Jennifer Marogi. The views expressed herein are those of the author(s) and not necessarily those of the National Bureau of Economic Research.

(C2004 by Hope Corman, Kelly Noonan, Nancy E. Reichman, and Dhaval Dave . All rights reserved. Short sections of text, not to exceed two paragraphs, may be quoted without explicit permission provided that full credit, including (C) notice, is given to the source. 
Demand for Illicit Drugs by Pregnant Women

Hope Corman, Kelly Noonan, Nancy E. Reichman, and Dhaval Dave

NBER Working Paper No. 10688

August 2004

JEL No. I18, K42

\title{
ABSTRACT
}

We use survey data that have been linked to medical records data and city-level drug prices to estimate the demand for illicit drugs among pregnant women. The prevalence of prenatal drug use based on post partum interviews was much lower than that based on evidence in the mothers' and babies' medical records. We found that a $\$ 10$ increase in the retail price of a gram of pure cocaine decreases illicit drug use by 12 to $15 \%$. The estimated price effects for heroin are lower than for cocaine and are less robust across alternative model specifications. This study provides the first estimates of the effects of drug prices on prenatal drug use and yields important information about the potential of drug enforcement as a tool for improving birth outcomes.

\author{
Hope Corman \\ Rider University \\ 2083 Lawrenceville Road \\ Lawrenceville, NJ 08648 \\ and NBER \\ corman@rider.edu \\ Kelly Noonan \\ Rider University \\ 2083 Lawrenceville Road \\ Lawrenceville, NJ 08648 \\ and NBER \\ knoonan@rider.edu \\ Nancy E. Reichman \\ Robert Wood Johnson Medical School \\ University of Medicine and Dentistry of \\ New Jersey \\ 97 Paterson Street, Room 435 \\ New Brunswick, NJ 08903 \\ reichmne@umdnj.edu
}

Dhaval Dave

University of Pennsylvania

Wharton School and National Bureau of Economic Research 365 Fifth Avenue, Suite 5318

New York, NY 10016-4309 


\section{Introduction}

Pregnant women can invest in the health of their unborn children through the use of prenatal inputs such as nutrition and prenatal care, and by avoiding unhealthy behaviors, such as smoking cigarettes and using drugs. Economists have been modeling the demand for prenatal care as an input into the production of infant health for about 20 years (for example, see Corman, Joyce and Grossman, 1987). Several studies have modeled the demand for cigarettes by pregnant women (see, for example, Evans and Ringel, 1999) and have estimated the price elasticity to be about -0.50 . From this result, they have concluded that higher taxes on tobacco have some potential to improve birth outcomes.

Less is known about the demand for illicit drugs among pregnant women. The lack of knowledge stems from a lack of data. Due to the illegal nature of drug transactions and stigma related to usage, pregnant women are especially likely to underreport drug usage in surveys. In this paper, we use survey from the Fragile Families and Child Wellbeing study that have been linked to medical records data and city-level drug prices to estimate the demand for illegal drugs among pregnant women. Our results provide the first estimates of the absolute and relative effects (compared to other factors) of drug prices on prenatal drug use and yield important information about the potential of drug enforcement as a tool for improving birth outcomes. 


\section{Background}

We know of no study that has estimated the demand for illicit drugs among pregnant women, although there are two sets of studies in the economics literature that are related to this topic. One set focuses on the demand for tobacco by pregnant women. The other examines the demand for illicit drugs in the population and estimates price elasticities or policy effects. Our study bridges these two literatures by estimating the demand for illicit drugs among pregnant women and calculating elasticities of participation with respect to drug prices.

Studies of the demand for tobacco products by pregnant women have been motivated by the fact that smoking is a behavior known to be harmful to both the mother and the developing fetus. Although much less is known about the effects of prenatal use of illicit drugs such as cocaine during pregnancy, there is reason to believe that such substances also have detrimental effects on the fetus. The medical literature on this topic is extensive but not conclusive; the most recent study we have found (Singer et al. 2004) indicates that prenatal cocaine exposure can increase the risk of certain cognitive impairments of offspring, particularly those raised in cognitively nonstimulating environments. One of the few studies by economists (Kaestner, Joyce and Wehbeh, 1996) found that illicit drug use during pregnancy reduces birth weight by 5 to 10 percent. Overall, the evidence, though limited, squares with the common sense notion that illicit drug use during pregnancy is harmful to the fetus.

We first discuss the literature on the demand for illicit drugs and then go over the relevant literature on smoking during pregnancy. In a recent comprehensive literature review, Grossman, Chaloupka, and Shim (2002) reported that most studies examining the demand for illicit drugs are based on two surveys: the National Household Survey on Drug Abuse (NHSDA) and the national Monitoring the Future survey. Both of these data sets contain self-reported measures of 
drug use (versus objective measures) and it is therefore possible that misreporting is correlated with the intensity of drug use (i.e., the lightest users may be the most or the least likely to report having used drugs). According to Grossman, Chaloupka, and Shim, the existing literature reveals that the demand for cocaine among teens and young adults is more price elastic than that among older adults.

Grossman and Chaloupka (1998) estimated the demand for cocaine using Monitoring the Future data within a "rational addiction" framework. They focused on cocaine because it was the second most frequently reported drug (after marijuana) in their data set and because good estimates of price are available. In their rational addiction specification, which controlled for past and future participation, they found that the short-run participation elasticity among youths in grades 8 through 12 was about -1.0 .

Saffer and Chaloupka (1999a) used the NHSDA to estimate participation elasticities of demand for heroin, cocaine, and marijuana. They found that annual participation elasticities varied between -0.30 and -0.60 for cocaine and between -0.60 and -0.90 for heroin. Because the NHSDA sample represents the overall population and Monitoring the Future is a youth sample, it is not surprising to find lower participation elasticities in the NHSDA.

In another study using the NHSDA, Saffer and Chaloupka (1999b) estimated cocaine elasticities for different demographic groups and found that they were higher for women and youth than for the overall sample. Given these patterns, we would expect that urban unmarried women (a broad characterization of the sample we use in the current paper) would have high cocaine participation elasticities. Finally, Saffer, Chaloupka, and Dave (2001) found, in both structural and reduced-form models, that illicit drug use varies inversely with state expenditures 
for drug control. This result indicates that it may be important to control for state policies when examining variations in the demand for illicit drugs.

The current study examines prenatal usage of illicit drugs within a cohort of urban, mostly unmarried women who have just given birth. Our sample is not representative of the population of pregnant women, for three reasons: (1) Non-marital births are overrepresented, (2) births were sampled exclusively in large cities, and (3) there may be sample selection bias, since drug usage may affect both the probability of becoming pregnant and the decision whether or not to abort. For all of these reasons, our sample of new mothers is likely to over-represent prenatal drug abusers.

Mensch and Kandel (1992), examining data from the National Longitudinal Survey of Youth (NLSY), found that unmarried teens who use drugs other than marijuana are almost four times as likely to become pregnant as those who did not; although they are also more likely to have abortions, their pregnancies are more than twice as likely to result in live births. In contrast, Grossman, Kaestner and Markowitz (2002), using more recent data from the NLSY, did not find conclusive evidence that alcohol and marijuana use by teens leads to increased risky sexual behavior. They concluded that omitted characteristics, such as tastes for risky behavior, likely explain the association between drug use and teenage pregnancy. Taken together, this small literature leaves us uncertain about the extent of selection bias in our sample of urban, mostly non-marital births.

Though not necessarily representative of all pregnant women, our sample of urban, mostly unmarried mothers who have given birth represents an important group to study from a public policy standpoint in that it is likely to include chronic or heavy users and consists of the very users that impose some of the heaviest costs on infants and society. 
Cigarette smoking among pregnant women has received a great deal of attention in the public health arena. Economists have examined the role that cigarette prices play in determining the demand for this risky behavior. A recent paper by Colman, Grossman and Joyce (2003) provided an excellent review of recent literature on the demand for cigarette smoking by pregnant women. They cite studies by Evans and Ringel (1999), Ringel and Evans (2001), Gruber and Köszegi (2001), and Ebrahim et al. (2000), among others. Based on vital statistics data, these studies revealed participation elasticities ranging from about -0.2 to -0.7 . Colman, Grossman and Joyce (2003) addressed the issue of quit rates during pregnancy, and explored the possibility that pregnant women may be more sensitive to price changes than non-pregnant women. Using Pregnancy Risk Assessment Monitoring System (PRAMS) data, they found high sensitivities of pregnant and pre-pregnant women to increases in cigarette prices - elasticities that were closer to -1.0 than those found in studies measuring price elasticities in the broader (mostly non-pregnant) population. They provided convincing evidence that women who are pregnant are more sensitive to price changes than non-pregnant women because of the added total costs (in terms of the health of the unborn child) of smoking.

Overall, the literature indicates that both drug users and pregnant women who smoke are fairly sensitive to variations in price. We know of no other study that has examined variations in drug prices as a factor in affecting drug use among pregnant women. The main reason for the dearth of research on this topic is the lack of accurate data on prenatal drug use. We combine high quality data on prenatal drug use obtained from both medical records and maternal interviews with city-level data on drug prices to conduct the first ever study of the price responsiveness of prenatal drug use. 


\section{Data}

We use data from a recent national birth cohort survey that has been linked to medical records of mother respondents and their babies. The Fragile Families and Child Wellbeing (FFCWB) survey follows a cohort of new parents and their children in 20 U.S. cities (in 15 states). The study was designed to provide information about the conditions and capabilities of new (mostly unwed) parents; the nature, determinants, and trajectories of their relationships; and the long-term consequences for parents and children of welfare reform and other policies. The survey data are rich in sociodemographic characteristics of both mothers and fathers, as well as parents' relationships and living arrangements.

The FFCWB study randomly sampled births in 75 hospitals between 1998 and 2000. By design, approximately three quarters of the mothers interviewed were unmarried. Face-to-face interviews were conducted with 4898 mothers while they were still in the hospital after giving birth. The data, when weighted, are representative of births in U.S. cities with over 200,000 people. ${ }^{1}$ Additional data have been collected from the hospital medical records (from the birth) for a sub-sample of 1867 births in 10 cities (in 7 states). The medical record data contain information on prenatal drug use from laboratory tests of the mother or baby and from notes by physicians or social workers (more detail is given below, under "Measures").

In this paper, we use data on the 1748 births that have medical records data as well as complete data on all analysis variables.

\footnotetext{
${ }^{1}$ Additional background on the research design of the Fragile Families and Child Wellbeing Study is available in Reichman et al. (2001).
} 


\section{Measures}

\section{$\underline{\text { A. Prenatal drug use }}$}

Prenatal drug use is notoriously underreported. The illegal nature of drug use and the fear of child protective services involvement are likely reasons for this. Kaestner, Joyce and Wehbeh (1996) modeled the measurement error in self-reported drug use by combining data on selfreports with "actual use" based on urine tests. They found that only $17 \%$ of women who tested positive for illicit drug use at the time their children were born reported that they had used drugs.

Arendt et al (1999) compared the sensitivity of different sources of data on prenatal cocaine use for 323 births: medical records, urine screens, meconium analyses, and postpartum interviews. They assumed no false positives from any source. Surprisingly, the clinical measures (urine and meconium screens, together) revealed fewer cases of cocaine use than medical records in conjunction with post-partum interviews. They concluded that a combination of medical records analysis and post-partum interview is the best way to ascertain prenatal cocaine use.

Although the Fragile Families interview was far less detailed on the issue of illicit drug use than the one used by Arendt et al., we adopted the strategy of combining responses to a postpartum survey with a detailed review of the mothers' and babies' medical records. During the mother's interview in the hospital after giving birth, she was asked whether she had used any illicit drugs during her pregnancy, but not about the use of specific types of drugs. ${ }^{2}$ In the medical records of the mother and baby, there were a number of places where prenatal drug use could have been mentioned.

\footnotetext{
${ }^{2}$ The exact question asked was, " During your pregnancy, about how often did you use drugs such as marijuana, crack cocaine, or heroin-- nearly every day, several times a week, several times a month, less than once a month, or never." When coding prenatal drug use based on the interview responses, those answering anything but "never" were considered prenatal drug users.
} 
The medical records contained information about the mother's drug use during pregnancy from laboratory test results on the mother or baby and in notes by physicians, nurses, or social workers. Forty four percent of the 1748 mothers in our sample had results from urine toxin screens in their charts ${ }^{3}$; of these $99(13 \%)$ tested positive for cocaine, heroin, marijuana, other drugs (including amphetamines, methadone and barbiturates/benzioazepines) or unspecified drugs, or a combination of drugs.

Another 91 cases of prenatal drug use were picked up from notes in various places in the mothers' and babies' charts. Overall, 190 (10.9\%) of the mothers in our sample had some indication of prenatal drug use recorded in their own or their babies' charts; of these, 17 percent used cocaine, 4 percent used heroin, 47 percent used marijuana, 4 percent used other drugs (including amphetamines, methadone and barbiturates/benzioazepines) or unspecified drugs, and 28 percent used a combination of drugs.

We constructed three measures of prenatal drug use: whether the mother indicated in the interview that she had used illicit drugs at all during the pregnancy $(5.7 \%)$, whether there was any indication of prenatal drug use in the mother's or baby's medical record (10.9\%), and whether there was indication of prenatal drug use from the interview or medical records (11.5\%). The percentages based on medical records are high and in the range presented in a review of sixteen studies by Howell, Heiser, and Harrington (1999). They also are consistent with the rates found in a recent survey that asked individuals whether they were pregnant, and if they were, whether they had used any illicit drug in the past year (about 14\%) or in the past month (about $5 \%)(\text { SAMHSA } 2000)^{4}$.

\footnotetext{
${ }^{3}$ Unlike the Arendt et al. study, urine screens were not collected as a part of the FFCWB data study. Rather, the screens were conducted during the normal course of medical care.

${ }^{4}$ SAMHSA (Substance Abuse and Mental Health Services Administration) http://webapp.icpsr.umich.edu/cocoon/SAMHDA-STUDY/03262.xml.
} 
Table 1 shows the levels of agreement between the two sources of reports. Of the 100 mothers who reported having used drugs in the interview, $89 \%$ had evidence of prenatal drug use in the medical records. Of the 190 mothers with evidence of prenatal drug use in the medical records, less than $47 \%$ reported in the interview that they had used drugs. It is thus clear that the interviews missed a large number of cases of actual drug use. Because it is unlikely that mothers would report that they had used drugs during pregnancy when they actually had not and because the medical record evidence of drug use also is unlikely to be incorrect, we base most of our analyses on the measure of whether the mother reported in the interview that she used drugs or there was evidence in the medical records that she had done so (11.5\% of sample). We refer to this measure as the "either/or" measure.

\section{B. Drug Prices}

Data on cocaine and heroin prices for the ten metropolitan areas in this study were computed from purchases made by undercover drug enforcement agents. The System to Retrieve Information from Drug Evidence (STRIDE), maintained by the Drug Enforcement Agency (DEA), records the total cost, amount, and potency of these drug purchases. ${ }^{5}$ Since these data are based on actual transactions, they directly reflect street level prices. These prices are expected to be relatively accurate because any unreasonable price offered by a DEA agent may raise suspicion on the dealer's part and endanger the agent. However, because the transactions are of varying quantity and quality, the cost of each drug must be standardized. ${ }^{6}$

Standardized prices of one pure gram of cocaine and heroin in a given metropolitan area for a given year are derived in the following manner:

$$
\log \operatorname{Cost}_{\mathrm{ijt}}=\pi_{0}+\pi_{1} \log \text { Potency }_{\mathrm{ijt}}+\pi_{2} \log \text { Amount }_{\mathrm{ijt}}+\pi_{3 \mathrm{j}} \sum \mathrm{MSA}_{\mathrm{j}}
$$

\footnotetext{
${ }^{5}$ Data on marijuana prices are too limited to include in this analysis.

${ }^{6}$ See Dave (2004) and Saffer and Chaloupka (1999a) for further discussion of STRIDE.
} 


$$
+\pi_{4 \mathrm{t}} \text { Year }_{\mathrm{t}}+\pi_{5 \mathrm{jt}} \sum \mathrm{MSA}_{\mathrm{j}} * \mathrm{Year}_{\mathrm{t}}+\mathrm{v}_{\mathrm{ijt}}
$$

The subscripts denote the $\mathrm{i}^{\text {th }}$ transaction in the $\mathrm{j}^{\text {th }}$ metropolitan area (MSA) for year $\mathrm{t}$. Cost refers to the total cost of the purchase, amount is the total gram weight of the purchase, and potency is the percent of the total amount that represents pure drug. MSA and year refer to dichotomous indicators of each, and $M S A^{*}$ Year refers to indicators of the interaction between the two.

Because we are interested in the retail price of heroin, we include only buys of 40 grams or less. The price of one pure gram of the drug in MSA $j$ for year $t$ is then imputed as:

$$
\exp \left(\pi_{0}+\pi_{3 \mathrm{j}}+\pi_{4 \mathrm{t}}+\pi_{5 \mathrm{jt}}\right)
$$

In order to maximize the sample size for estimation, prices that are missing in any given metropolitan area for any given year were imputed by the mean of the prices for all other available metropolitan areas in that particular state. ${ }^{7}$ The strong addictive properties of cocaine and heroin imply an intertemporal reinforcement effect wherein current consumption is positively affected by past consumption. ${ }^{8}$ Thus, current drug use will be affected by past drug prices in addition to the current price. In order to maximize the variation in drug prices and minimize collinearity in our small sample, a three-year average of the cocaine and heroin price was used in the analysis, based on the year of birth and the two preceding years. ${ }^{9}$ This measure allowed for both contemporaneous and lagged effects of prices on prenatal drug use. ${ }^{10}$

One of the advantages of this study is that the drug prices are computed and merged at the city level. Many prior studies on the demand for illicit drugs used state-average prices despite

\footnotetext{
${ }^{7}$ Results were not sensitive to this imputation.

${ }^{8}$ See Chaloupka et al. (2000) and Dave (2004).

${ }^{9}$ The births took place over a three-year period, from 1998 to 2000 . Because we employed three-year averages, the drug prices span 1996-1998 for the women interviewed in 1998, and 1998-2000 for the women interviewed in 2000. In order to ensure that our results are not affected by changes in drug price over time, we examined trends from 1996 to 2000. For both cocaine and heroin, we found no clear trends in real prices per pure gram over this period. As data from more cities and years become available, we will be able to distinguish between short- and long-run price effects.

${ }^{10}$ Using two-year average drug prices did not materially change the results.
} 
the fact that drug prices seem to vary widely from city to city. Granted, there may be substantial intra-city variation in drug prices at any given time, but the measurement error is likely to be much smaller using city-level than state-level prices. Studies have also shown that the drug price measures from STRIDE are strongly correlated with the cost of supplying drugs to the retail market. Kuziemko and Levitt (2001) found that STRIDE cocaine prices from 1986 through 1996 are positively related to state-level indicators of the certainty of punishment, measured by the per capita number of drug arrests, and the severity of punishment, measured by the fraction of drug arrests resulting in imprisonment. Basov, Jacobson, and Miron (2001) argued that due to the illicit, secretive nature of the drug trade, both production and sales are labor intensive compared to legal markets. Most of these jobs are also likely to be filled by low-skilled employees, youths, or others with fewer outside opportunities. Their study showed that cocaine and heroin prices from STRIDE are positively related to the state-specific relative unskilled wage in a time series of states from 1974 to 1999 . The results from these two studies confirm that DEA drug prices do indeed reflect costs of retailing including expected penalties associated with this activity and labor costs.

\section{Control variables}

One of the advantages of the FFCWB data is that they include a rich set of characteristics of both the mother and the father. Table 2 shows the means of the variables used in our analyses. We include a basic set of covariates that are typically available in birth certificate data - maternal age, education, race/ethnicity, nativity, marital status, and previous births. We also include insurance information (whether the birth was covered by Medicaid), whether the mother lived with both parents at age 15 , whether she attended religious services regularly, whether she was 
married at the time of conception (instead of at the time of the birth), ${ }^{11}$ how long she knew the father before conception, the father's age, and the father's education.

In order to control for city-specific factors that may affect both city-level drug prices and drug use, we include characteristics of the mother's city of residence (unemployment rate and median yearly family income) in certain models. In other models, we include state fixed effects to control for state-level policies, such as the funding of drug treatment programs or the strictness of drug enforcement, which may affect prenatal drug use. ${ }^{12}$

Our analyses focus on the effects of retail drug prices on drug use during pregnancy. As shown in Table 2, the mean retail price of one pure gram of cocaine is about $\$ 90$ with a standard deviation of $\$ 22$, and the mean price of one pure gram of heroin is about $\$ 214$ with a standard deviation of $\$ 66$. These prices are deflated by the national CPI and reported in constant 2000 dollars (in $\$ 10$ denomination). Both price series move together with a simple correlation of 0.63 (not shown in Table).

As is clear from Table 2, the mothers in the sample are predominantly minority, unmarried (as indicated earlier, this was by design), and poor or near-poor (two-thirds of births were covered by Medicaid or another government program). The third and fourth columns show the characteristics of the sample by whether or not the mothers used drugs during pregnancy (based on the either/or measure). Although both users and non-users were about the same mean age, 25 years old, they differed with regard to race/ethnicity, poverty (as indicated by Medicaid receipt), marital status, and whether the mother was an immigrant. Over one-quarter (26\%) of the

\footnotetext{
${ }^{11}$ This variable is based on marriage dates, birth dates, and the baby's gestational age.

${ }^{12}$ Because our sample includes data from 10 cities in only 7 states, we face certain limitations. First, we could not investigate the effects of state policy variations. Instead, in certain models, we included state fixed effects to hold constant the entire state policy regime. Second, because of limited variation in both the number of states and in the city-level drug prices, particularly for heroin prices, there may be collinearity between state fixed effects and drug prices. For this reason, we estimate models both with and without state fixed effects. Finally, there was not enough city variation within states to include both state fixed effects and city-level variables in the same models.
} 
non-users were married at the time of the birth, compared to only $8 \%$ of the drug users. There was a larger mean age difference between the mother and the father among the drug users than the non-users. Users were less likely than non-users to attend religious services regularly and to have lived with both parents at age 15 . Drug users were more likely than non-users to live in cities with high unemployment rates and low incomes. The non-users were more likely than the drug users to be having their first birth. Importantly, the mean city-level drug prices of both cocaine and heroin were higher for the non-drug users than for the drug users. In order to control for confounding influences of other factors on this association (between drug prices and prenatal drug use), we turn to multivariate models.

\section{Multivariate Analysis}

We estimate the use of drugs during pregnancy based on maternal characteristics, paternal measures, either city-level economic characteristics or state fixed effects, and three-year averages of cocaine or heroin prices in the metropolitan area where the baby was born. ${ }^{13}$ As is typically done in studies of the demand for drugs, we assume that drug prices are exogenous to the women in our sample. ${ }^{14}$

In Tables $3 \mathrm{a}$ (with cocaine prices) and $3 \mathrm{~b}$ (with heroin prices), we present estimates from probit models in which the dependent variable is equal to one if the mother used drugs according to the either/or measure. Each column corresponds to a different model specification. We present the probit coefficient, the standard error (in parentheses), and the marginal effect of a one-unit change in that variable on the probability that the mother used drugs during the pregnancy [in

\footnotetext{
${ }^{13}$ Because of the high degree of correlation between the two price measures, models were not run with both measures included.
} 
square brackets]. For example, in column (1) of Table 3a, the probit coefficient of the mother being a high school graduate (as opposed to having less than a high school education, the reference category), is -.241 and the marginal effect of -0.033 , which means that being a high school graduate reduces the probability that the mother used drugs during pregnancy by 3.3 percentage points compared to having less than a high school education, all else equal.

In both Tables $3 \mathrm{a}$ and $3 \mathrm{~b}$, Model 1 includes a basic set of covariates that are typically found in birth records, plus the real average retail cocaine (heroin) price per pure gram (expressed in \$10 denominations for the base year of 2000). Model 2 includes the same set of basic covariates plus state fixed effects. Model 3 includes the same set of basic covariates as in Model 1, plus city-level median yearly family income rather than state fixed effects. ${ }^{15}$ Model 4 includes additional or more refined measures of maternal characteristics - whether the birth was covered by Medicaid, whether the mother lived with both parents when she was 15 years of age, whether she was married at the time of conception rather than at the birth, whether she knew the father for at least one year before the baby was conceived, whether the father had at least a high school education, the age difference between the father and the mother, and whether the mother attended religious services on a regular basis - as well as cocaine (heroin) prices and state fixed effects. Finally, Model 5 includes all of the covariates in Model 4 plus city-level median yearly family income rather than state fixed effects.

\footnotetext{
${ }^{14}$ One reason researchers make this assumption is that cocaine and heroin are basically agricultural goods that cost little to produce. The supply price is then a function of the supply of workers willing to risk penalties to engage in the production and sale of the retail product, and the expected penalties imposed by local governments.

${ }^{15}$ In another specification not shown, we substituted city-level unemployment for city-level income. Results were similar to the ones presented here. Data limitations did not allow us to include state- and multiple city-level variables in the same equations.
} 
Both low education and poverty (proxied by Medicaid) increased the likelihood that mothers used drugs during pregnancy. ${ }^{16}$ Hispanic women were less likely to use drugs than nonHispanic white or non-Hispanic black women, all else equal. Having had previous births did not seem to impact prenatal drug usage in our sample, but being married to the baby's father at the time of the birth was negatively associated with drug use during pregnancy. Mothers born outside the United States were less likely to use drugs than native-born mothers, and the more the father's age exceeds the mother's, the more likely the mother used drugs. Overall, the results for the maternal and paternal characteristics are consistent with our prior expectations (based on the past studies of the determinants of drug use and prenatal smoking). As a group, the state fixed effects are significant predictors of prenatal drug use, suggesting that policies may affect maternal behavior. These results hold whether we use cocaine or heroin prices in our models.

From Table 3a, we find that cocaine prices per pure gram have consistent and significant effects on mothers' use of drugs during pregnancy. The marginal effects vary between -.014 and -.017 , which means that a $\$ 10$ increase in the price of a gram of pure cocaine decreases illicit drug use by 12 to $15 \% .{ }^{17}$ From Table $3 \mathrm{~b}$, we find that heroin prices also have a significant effect on illicit drug use in models that do not include state fixed effects ${ }^{18}$, with a $\$ 10$ increase in price decreasing prenatal drug use by 4 to $5 \% .{ }^{19}$ We take advantage of having different sources of data on mothers' drug use to examine how much of a difference the choice of measure makes. Tables 4a and $4 \mathrm{~b}$ show "Model 5"estimates using three different measures of prenatal drug use: That based only on the interview (columns 1 and 2), that based only on the medical records (columns

\footnotetext{
${ }^{16}$ It is possible that drug usage causes women to have income low enough to qualify for means-tested programs such as Medicaid. If this were true, then we are measuring causality in the wrong direction. This is also possible with some of our other variables such as marital status, age difference, and other variables. In our sensitivity analyses, discussed below, we address such possible biases for covariates other than drug prices.

${ }^{17}$ We divide the marginal effects by .115 , the proportion of the sample that used drugs during pregnancy.

${ }^{18}$ As discussed earlier, it appears that there is collinearity between the state fixed effects and heroin prices.

${ }^{19}$ The estimates pertain to models 1,3 , and 5 .
} 
3 and 4), and that based on the either/or measure (columns 5 and 6). The last two columns are identical to Model 5 in each of Tables 3a and 3b. We would expect the marginal effects in column (2) to be lower than those in column (6), since less than half of the women who used drugs (according to the either/or measure) responded positively to the interview question. Indeed, for either cocaine or heroin, the marginal effect of a $\$ 10$ increase in price on the proportion of pregnant women using drugs was about three times greater when using data from medical records or interviews as opposed to using the interview data alone. Additionally, the statistical significance was greater when using the either/or measure. The differences in effect size indicate that relying solely on self-reported drug use would lead one to underestimate the responsiveness of prenatal drug use to variations in price. ${ }^{20}$ The differences in statistical significance suggest that analyses based on self-reported drug usage are prone to Type II errors (incorrectly "accepting" the null hypothesis of no price effect).

Table 5 indicates the ranges of the demand elasticities implied by the results of Models 1 though 5, using each of the three drug use measures: maternal interview, medical reports, and the either/or measure. The elasticities are based on mean values of drug usage and drug prices. For cocaine prices, elasticities range between -.77 and -1.37 . Though higher than those from studies cited earlier, these elasticities are credible in light of past research indicating that women and youth have higher participation elasticities than other groups and that pregnant women are more responsive to drug prices than non-pregnant women. Heroin price elasticities vary more than cocaine prices across specifications with and without state fixed effects. However, the higher estimates of heroin price elasticity are close to the price elasticities of cocaine.

\footnotetext{
${ }^{20}$ The rate of drug usage based either/or measure is about twice as high as that based on the interviews alone and the coefficients of drug prices are about three times as large. Thus, relying on the interviews alone would underestimate the price responsiveness of prenatal drug usage due to both the underreporting of drug usage and the greater price
} 
We examined several alternative specifications to test the robustness of our results. First, we took into consideration that our measure of drug use is somewhat imprecise in that we combined all illicit drugs together. In our sample, as in the SAMHSA survey discussed earlier, many women used marijuana, a less powerful and addictive drug than cocaine and most others. In addition, a few of the women in our survey used methadone, which may not be illegal. As a sensitivity test, we ran models excluding women who we know used only methadone or marijuana. The results (not shown) were highly consistent with those in Tables $3 \mathrm{a}$ and $3 \mathrm{~b}$ and elasticities were very similar to those in Table 5. Additionally, since many of the covariates other than drug prices may be endogenous (as discussed earlier), we ran additional models that included only age, race, education, and drug prices (plus state fixed effects or city income level)—variables are unlikely to be influenced by drug usage or unobserved individual-level characteristics. Results of the effect of drug prices on drug usage in these models are similar to those found in Tables $3 \mathrm{a}$ and $3 \mathrm{~b}$. The consistency of the price effects across alternative specifications suggests that they do not reflect unobserved factors. Finally, we ran models that also consider two prenatal behaviors other than drug use - smoking cigarettes at all during the pregnancy (from the survey) and first-trimester initiation of prenatal care (from the medical record). These variables may reflect a taste (or distaste) for risky behaviors, but are endogenous in that they could be "caused" by drug use or correlated with risk factors that are unobserved. To the extent that these behaviors are exogenous to drug usage, they may proxy the mother's taste for risky behaviors during the pregnancy. Holding these other risky behaviors constant, the effects of drug prices on drug usage were within the range of those presented in Tables $3 \mathrm{a}$ through $4 b$.

sensitivity among those who used drugs (based on the either/or measure) but indicated in the interview that they had not. 


\section{Conclusion}

We found that the demand for illicit drugs among pregnant women is quite responsive to drug prices. This is an important finding because impacting prices is one of the key methods by which the public sector can affect the demand for illicit, unhealthy substances and is potentially one of the key weapons in the war on drugs. As we expected based on the literature reviewed earlier, the participation elasticities with respect to price for our sample are much higher than those that have been found for the general population, for three reasons: (1) Our sample is exclusively urban and over-represents unmarried, young, minority women. For this group, the monetary price of drugs represents a larger portion of the full price of drugs (since their opportunity cost of time is lower). Thus, a given change in the monetary price represents a large change in the full price, yielding a larger consumption response and a larger elasticity. (2) Pregnant women are likely more rational/forward looking than non-pregnant women. Thus, they may have a lower reservation price for using drugs, since they are also taking into account the future consequences on their babies of their current behavior. With a lower reservation price, a given increase in drug prices will cause more pregnant women to quit than non-pregnant women, yielding a higher elasticity. (3) We used an objective measure of drug use that likely captured casual (more elastic) drug use not picked up in the interviews. The fact that measures of prenatal drug use based on medical records yield higher participation elasticities than those based on self reports from maternal interviews suggests that results based on self-reported drug use should be interpreted with caution. 


\section{References}

Arendt, R. E., L. T. Singer, S. Minnes and A. Salvator. (1999). "Accuracy in Detecting Prenatal Drug Exposure." Journal of Drug Issues 29(2): 203-214.

Basov, S., M. Jacobson and J. Miron. (2001). "Prohibition and the Market for Illegal Drugs: An Overview of Recent History." World Economics 2(4): 133-158.

Chaloupka, F. J., F. J. Tauras and M. Grossman. (2000). "The Economics of Addiction." Pp. in Tobacco Control in Developing Countries. edited by P. Jha and F. Chaloupka. New York, Oxford University Press.

Colman, G., M. Grossman and T. Joyce. (2003). "The Effect of Cigarette Excise Taxes on Smoking Before, During, and After Pregnancy." Journal of Health Economics 22(6): 1053-1072.

Corman, H., T. Joyce and M. Grossman. (1987). "Birth Outcome Production Function in the United States." The Journal of Human Resources 22(3): 339-360.

Dave, D. (2004). "The Effect of Cocaine and Heroin Prices on Drug Use Among Arrestees." Working Paper (New York: City University of New York).

Ebrahim, S. H., R. L. Floyd, R. K. Merritt, P. Decoufle and D. Holtzman. (2000). "Trends in Pregnancy-Related Smoking Rates in the United States, 1987-1996." Journal of the American Medical Association 283(3): 361-366.

Evans, W. N. and J. S. Ringel. (1999). "Can Higher Cigarette Taxes Improve Birth Outcomes?" Journal of Public Economics 72(1): 135-154.

Grossman, M. and F. J. Chaloupka. (1998). "The Demand for Cocaine By Young Adults: A Rational Addiction Approach." Journal of Health Economics 17(4): 427.

Grossman, M., F. J. Chaloupka and K. Shim. (2002). "Illegal Drug Use and Public Policy." Health Affairs 21(2): 134.

Grossman, M., R. Kaestner and S. Markowitz. (2002). "Get High and Get Stupid: The Effect of Alcohol and Marijuana Use on Teen Sexual Behavior." NBER Working Paper: 9216. National Institute on Drug Abuse

Gruber, J. and B. Koszegi. (2001). "Is Addiction 'Rational'? Theory and Evidence." Quarterly Journal of Economics 116(4): 1261-1303.

Howell, E. M., N. Heiser and M. Harrington. (1999). "A Review of Recent Findings on Substance Abuse Treatment for Pregnant Women." Journal of Substance Abuse 
Treatment 16(3): 195-219.

Kaestner, R., T. Joyce and H. Wehbeh. (1996). "The Effect of Maternal Drug Use on Birth Weight: Measurement Error in Binary Variables." Economic Inquiry 34(4): 617-629.

Kuziemko, I. and S. Levitt. (2001). "An Empirical Analysis of Imprisoning Drug Offenders." NBER Working Paper \# w8489. Cambridge

Mensch, B. and D. B. Kandel. (1992). "Drug Use as a Risk Factor for Premarital Teen Pregnancy and Abortion in a National Sample of Young White Women." Demography 29(3): 409429.

Reichman, N. E., J. O. Teitler, I. Garfinkel and S. S. McLanahan. (2001). "Fragile Families: Sample and Design." Children and Youth Services Review 23(4/5): 303-326.

Ringel, J. S. and W. N. Evans. (2001). "Cigarette Taxes and Smoking During Pregnancy." American Journal of Public Health 91(11): 1851-56.

Saffer, H. and F. Chaloupka. (1999a). "The Demand for Illicit Drugs." Economic Inquiry 37(1): 401-411.

-----. (1999b). "Demographic Differentials in the Demand for Alcohol and Illicit Drugs." Pp. in The Economic Analysis of Substance Use and Abuse. edited by. Chicago, Univ. of Chigago Press.

Saffer, H., F. Chaloupka and D. Dave. (2001). "State Drug Control Spending and Illicit Drug Participation." Contemporary Economic Policy 19(2): 150-161.

Singer, L. T., S. Minnes, E. Short, R. E. Arendt, K. Farkas, B. Lewis, N. Klein, S. Russ, M. O. Min and H. L. Kirchner. (2004). "Cognitive Outcomes of Preschool Children With Prenatal Cocaine Exposure." Journal of the American Medical Association 291(20): 2448-2456. 
Table 1

Mothers' drug use during pregnancy, by source of report

\begin{tabular}{|c|c|c|c|}
\hline \multirow{2}{*}{ Interview: } & \multicolumn{2}{|c|}{ Medical Records } & \\
\hline \multirow{2}{*}{ No } & \multicolumn{2}{|c|}{ No } & Yes \\
& 1547 & 101 & 1648 \\
& .885 & .058 & .943 \\
\hline \multirow{2}{*}{ Yes } & 11 & 89 & 100 \\
& .006 & .051 & .057 \\
& 1558 & 190 & 1748 \\
& .089 & .109 & 1.00 \\
\hline
\end{tabular}

Note: Shaded cells are included in our "either/or" definition of prenatal drug use 
Table 2: Means

\begin{tabular}{|c|c|c|c|}
\hline & $\begin{array}{c}\text { All Mothers } \\
\text { Mean } \\
\text { (Standard Deviation) }\end{array}$ & $\begin{array}{c}\text { Drug Users }^{\mathbf{a}} \\
\text { Mean } \\
\text { (Standard Deviation) }\end{array}$ & $\begin{array}{c}\text { Non-Drug Users } \\
\text { Mean } \\
\text { (Standard Deviation) }\end{array}$ \\
\hline $\begin{array}{l}\text { Prenatal Drug Use } \\
\text { According to Interview }\end{array}$ & .057 & .497 & $0^{*}$ \\
\hline According to Medical Record & .109 & .945 & $0^{*}$ \\
\hline Interview or Medical Chart & .115 & 1 & 0 \\
\hline \multicolumn{4}{|l|}{ Mother's Characteristics } \\
\hline Age (years) & $\begin{array}{l}24.99 \\
(5.98)\end{array}$ & $\begin{array}{l}24.70 \\
(6.04)\end{array}$ & $\begin{array}{l}25.02 \\
(5.98)\end{array}$ \\
\hline High School Grad & .30 & .35 & .30 \\
\hline Some College & .23 & .16 & .24 \\
\hline College Grad & .10 & .02 & $.11^{*}$ \\
\hline Medicaid Birth & .67 & .85 & $.64^{*}$ \\
\hline Hispanic & .37 & .19 & $.39^{*}$ \\
\hline Black & .41 & .65 & $.38^{*}$ \\
\hline $\begin{array}{l}\text { 'Other' Race } \\
\text { (Not White, Black, or Hispanic) }\end{array}$ & .05 & .02 & .05 \\
\hline Immigrant & .19 & .02 & $.21^{*}$ \\
\hline Lived with Both Parents at Age 15 & .44 & .31 & $.45^{*}$ \\
\hline $\begin{array}{l}\text { Attended Religious Services Several } \\
\text { Times/Month }\end{array}$ & .39 & .26 & $.40^{*}$ \\
\hline First Birth & .37 & .27 & $.39^{*}$ \\
\hline Number of Pregnancies & .75 & .84 & $.74^{*}$ \\
\hline $\begin{array}{l}\text { Age Difference in Years (Father } \\
\text { minus Mother) }\end{array}$ & $\begin{array}{l}2.57 \\
(5.12)\end{array}$ & $\begin{array}{l}3.52 \\
(6.27)\end{array}$ & $\begin{array}{l}2.44^{*} \\
(4.93)\end{array}$ \\
\hline $\begin{array}{l}\text { Father's Characteristics } \\
\text { High School Grad }\end{array}$ & .63 & .56 & .64 \\
\hline
\end{tabular}


Table 2: Means

\begin{tabular}{|c|c|c|c|}
\hline 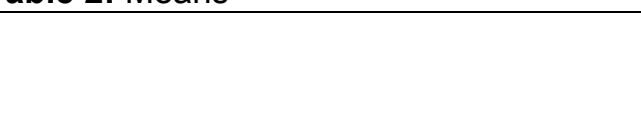 & $\begin{array}{c}\text { All Mothers } \\
\text { Mean } \\
\text { (Standard Deviation) } \\
\end{array}$ & $\begin{array}{c}\text { Drug Users } \\
\text { Mean } \\
\text { (Standard Deviation) } \\
\end{array}$ & $\begin{array}{c}\text { Non-Drug Users } \\
\text { Mean } \\
\text { (Standard Deviation) } \\
\end{array}$ \\
\hline $\begin{array}{l}\text { Parents' Relationship } \\
\text { Mother Knew Father } 12 \text { Months Prior } \\
\text { to Conception }\end{array}$ & .85. & .83 & .85. \\
\hline Married at Time of Conception & .23 & .08 & $.25^{*}$ \\
\hline $\begin{array}{c}\text { Married at Birth } \\
\text { City Characteristics }\end{array}$ & .24 & .08 & $.26^{*}$ \\
\hline $\begin{array}{l}\text { Median Yearly Family Income } \\
\text { (\$ Thousands) }\end{array}$ & $\begin{array}{c}46.607 \\
(12.801)\end{array}$ & $\begin{array}{l}42.487 \\
(92.17)\end{array}$ & $\begin{array}{l}47.143^{*} \\
(13.10)\end{array}$ \\
\hline Unemployment Rate & $\begin{array}{c}5.16 \\
(1.83)\end{array}$ & $\begin{array}{c}6.02 \\
(1.46)\end{array}$ & $\begin{array}{l}5.05^{*} \\
(1.85)\end{array}$ \\
\hline $\begin{array}{l}\text { Drug Prices } \\
3 \text { Year Average Cocaine Price } \\
\text { (Tens of } \$ \text { ) }\end{array}$ & $\begin{array}{l}8.80 \\
(2.18)\end{array}$ & $\begin{array}{l}8.33 \\
(2.06)\end{array}$ & $\begin{array}{l}8.86^{*} \\
(2.18)\end{array}$ \\
\hline $\begin{array}{l}3 \text { Year Average Heroin Price } \\
\text { (Tens of \$) }\end{array}$ & $\begin{array}{l}21.36 \\
(6.56)\end{array}$ & $\begin{array}{l}20.19 \\
(5.62)\end{array}$ & $\begin{array}{l}21.51^{*} \\
(6.66)\end{array}$ \\
\hline
\end{tabular}

${ }^{*}$ Difference between users and non-users significant at $1 \%$ level

${ }^{a}$ Prenatal drug use according to interview or medical records 
Table 3a: Drug Use during Pregnancy - Cocaine Prices

Dependent Variable - Drug Use from Interview or Medical Records

\begin{tabular}{|c|c|c|c|c|c|}
\hline & $\begin{array}{c}\text { Model 1 } \\
\text { Coefficient } \\
\text { (Standard Error) } \\
\text { [Marginal Effect] }\end{array}$ & $\begin{array}{c}\text { Model } 2 \\
\text { Coefficient } \\
\text { (Standard Error) } \\
\text { [Marginal Effect] }\end{array}$ & $\begin{array}{c}\text { Model 3 } \\
\text { Coefficient } \\
\text { (Standard Error) } \\
\text { [Marginal Effect] }\end{array}$ & $\begin{array}{c}\text { Model 4 } \\
\text { Coefficient } \\
\text { (Standard Error) } \\
\text { [Marginal Effect] }\end{array}$ & $\begin{array}{c}\text { Model 5 } \\
\text { Coefficient } \\
\text { (Standard Error) } \\
\text { [Marginal Effect] }\end{array}$ \\
\hline $\begin{array}{l}\text { Mother's Characteris } \\
\text { Age }\end{array}$ & $\begin{array}{l}.031 \\
(.031) \\
{[.005]}\end{array}$ & $\begin{array}{l}.026 \\
(.039) \\
{[.004]}\end{array}$ & $\begin{array}{l}.031 \\
(.031) \\
{[.005]}\end{array}$ & $\begin{array}{l}.017 \\
(.039) \\
{[.002]}\end{array}$ & $\begin{array}{l}.022 \\
(.030) \\
{[.003]}\end{array}$ \\
\hline Age Squared & $\begin{array}{l}-.000 \\
(.001) \\
{[-.000]}\end{array}$ & $\begin{array}{l}-.000 \\
(.001) \\
{[-.000]}\end{array}$ & $\begin{array}{l}-.000 \\
(.001) \\
{[-.000]}\end{array}$ & $\begin{array}{l}.000 \\
(.001) \\
{[.000]}\end{array}$ & $\begin{array}{l}.000 \\
(.001) \\
{[.000]}\end{array}$ \\
\hline High School Grad & $\begin{array}{l}-.241^{* *} \\
(.096) \\
{[-.033]}\end{array}$ & $\begin{array}{l}-.249^{* *} \\
(.100) \\
{[-.033]}\end{array}$ & $\begin{array}{l}-.246^{* * *} \\
(.095) \\
{[-.033]}\end{array}$ & $\begin{array}{l}-.165 \\
(.114) \\
{[-.021]}\end{array}$ & $\begin{array}{l}-.158 \\
(.105) \\
{[-.021]}\end{array}$ \\
\hline Some College & $\begin{array}{c}-.440^{* * *} \\
(.113) \\
{[-.054]}\end{array}$ & $\begin{array}{l}-.460^{* * *} \\
(.110) \\
{[-.054]}\end{array}$ & $\begin{array}{l}-.436^{* * *} \\
(.114) \\
{[-.054]}\end{array}$ & $\begin{array}{l}-.334^{* * *} \\
(.117) \\
{[-.039]}\end{array}$ & $\begin{array}{l}-.308^{* * *} \\
(.111) \\
{[-.038]}\end{array}$ \\
\hline College Grad & $\begin{array}{c}-1.002^{* * *} \\
(.162) \\
{[-.083]}\end{array}$ & $\begin{array}{c}-1.019^{* * *} \\
(.164) \\
{[-.080]}\end{array}$ & $\begin{array}{c}-1.009^{* * *} \\
(.160) \\
{[-.083]}\end{array}$ & $\begin{array}{c}-.919^{* * *} \\
(.229) \\
{[-.072]}\end{array}$ & $\begin{array}{c}-.904^{* * *} \\
(.218) \\
{[-.074]}\end{array}$ \\
\hline Medicaid & & & & $\begin{array}{l}.306^{\star \star} \\
(.140) \\
{[.038]}\end{array}$ & $\begin{array}{l}.327^{\star *} \\
(.148) \\
{[.042]}\end{array}$ \\
\hline Black & $\begin{array}{l}.071 \\
(.119) \\
{[.010]}\end{array}$ & $\begin{array}{l}.113 \\
(.133) \\
{[.016]}\end{array}$ & $\begin{array}{l}.025 \\
(.093) \\
{[.004]}\end{array}$ & $\begin{array}{l}.118 \\
(.142) \\
{[.016]}\end{array}$ & $\begin{array}{l}.037 \\
(.109) \\
{[.005]}\end{array}$ \\
\hline Hispanic & $\begin{array}{l}-.439^{* * *} \\
(.086) \\
{[-.059]}\end{array}$ & $\begin{array}{l}-.517^{* * *} \\
(.103) \\
{[-.066]}\end{array}$ & $\begin{array}{l}-.416^{* * *} \\
(.087) \\
{[-.056]}\end{array}$ & $\begin{array}{c}-.552^{* * *} \\
(.111) \\
{[-.064]}\end{array}$ & $\begin{array}{l}-.434^{* * *} \\
(.102) \\
{[-.056]}\end{array}$ \\
\hline
\end{tabular}


Table 3a: Drug Use during Pregnancy - Cocaine Prices

Dependent Variable - Drug Use from Interview or Medical Records

\begin{tabular}{|c|c|c|c|c|c|}
\hline & $\begin{array}{c}\text { Model 1 } \\
\text { Coefficient } \\
\text { (Standard Error) } \\
\text { [Marginal Effect] }\end{array}$ & $\begin{array}{c}\text { Model } 2 \\
\text { Coefficient } \\
\text { (Standard Error) } \\
\text { [Marginal Effect] }\end{array}$ & $\begin{array}{c}\text { Model } 3 \\
\text { Coefficient } \\
\text { (Standard Error) } \\
\text { [Marginal Effect] }\end{array}$ & $\begin{array}{c}\text { Model } 4 \\
\text { Coefficient } \\
\text { (Standard Error) } \\
\text { [Marginal Effect] }\end{array}$ & $\begin{array}{c}\text { Model } 5 \\
\text { Coefficient } \\
\text { (Standard Error) } \\
\text { [Marginal Effect] }\end{array}$ \\
\hline \multicolumn{6}{|l|}{ Mother's Characteristics (cont.) } \\
\hline $\begin{array}{l}\text { 'Other' Race } \\
\text { (Not White, Black, or Hispanic) }\end{array}$ & $\begin{array}{l}-.268 \\
(.294) \\
{[-.033]}\end{array}$ & $\begin{array}{l}-.273 \\
(.291) \\
{[-.032]}\end{array}$ & $\begin{array}{l}-.266 \\
(.286) \\
{[-.032]}\end{array}$ & $\begin{array}{l}-.236 \\
(.284) \\
{[-.027]}\end{array}$ & $\begin{array}{l}-.238 \\
(.279) \\
{[-.028]}\end{array}$ \\
\hline Immigrant & $\begin{array}{l}-1.012^{* * *} \\
(.128) \\
{[-.097]}\end{array}$ & $\begin{array}{l}-.992 * * * \\
(.187) \\
{[-.092]}\end{array}$ & $\begin{array}{l}-.964^{* * *} \\
(.176) \\
{[-.094]}\end{array}$ & $\begin{array}{c}-1.057^{* * *} \\
(.203) \\
{[-.092]}\end{array}$ & $\begin{array}{c}-1.032^{* * *} \\
(.196) \\
{[-.093]}\end{array}$ \\
\hline First Birth & $\begin{array}{l}-.068 \\
(.089) \\
{[-.010]}\end{array}$ & $\begin{array}{l}-.037 \\
(.094) \\
{[-.005]}\end{array}$ & $\begin{array}{l}-.068 \\
(.090) \\
{[-.010]}\end{array}$ & $\begin{array}{l}.030 \\
(.106) \\
{[.004]}\end{array}$ & $\begin{array}{l}.003 \\
(.102) \\
{[.000]}\end{array}$ \\
\hline Number of Pregnancies & $\begin{array}{l}.084 \\
(.102) \\
{[.012]}\end{array}$ & $\begin{array}{l}.118 \\
(.122) \\
{[.016]}\end{array}$ & $\begin{array}{l}.072 \\
(.108) \\
{[.010]}\end{array}$ & $\begin{array}{l}.107 \\
(.135) \\
{[.014]}\end{array}$ & $\begin{array}{l}.075 \\
(.123) \\
{[.010]}\end{array}$ \\
\hline Lived with Both Parents at Age 15 & & & & $\begin{array}{l}-.032 \\
(.055) \\
{[-.004]}\end{array}$ & $\begin{array}{l}-.016 \\
(.054) \\
{[-.002]}\end{array}$ \\
\hline $\begin{array}{l}\text { Attended Religious Services Several } \\
\text { Times/Month }\end{array}$ & & & & $\begin{array}{l}-.246^{* * *} \\
(.085) \\
{[-.032]}\end{array}$ & $\begin{array}{l}-.269^{* * *} \\
(.091) \\
{[-.036]}\end{array}$ \\
\hline $\begin{array}{l}\text { Age Difference Between Father and } \\
\text { Mother }\end{array}$ & & & & $\begin{array}{l}.026^{* \star *} \\
(.005) \\
{[.004]}\end{array}$ & $\begin{array}{l}.025^{* * *} \\
(.005) \\
{[.003]}\end{array}$ \\
\hline $\begin{array}{c}\text { Father Characteristics } \\
\text { High School Grad }\end{array}$ & & & & $\begin{array}{l}-.251^{* * *} \\
(.060) \\
{[-.036]}\end{array}$ & $\begin{array}{c}-.263^{* * *} \\
(.053) \\
{[-.038]}\end{array}$ \\
\hline
\end{tabular}


Table 3a: Drug Use during Pregnancy - Cocaine Prices

Dependent Variable - Drug Use from Interview or Medical Records

\begin{tabular}{|c|c|c|c|c|c|}
\hline & $\begin{array}{c}\text { Model 1 } \\
\text { Coefficient } \\
\text { (Standard Error) } \\
\text { [Marginal Effect] }\end{array}$ & $\begin{array}{c}\text { Model } 2 \\
\text { Coefficient } \\
\text { (Standard Error) } \\
\text { [Marginal Effect] }\end{array}$ & $\begin{array}{c}\text { Model } 3 \\
\text { Coefficient } \\
\text { (Standard Error) } \\
\text { [Marginal Effect] }\end{array}$ & $\begin{array}{c}\text { Model 4 } \\
\text { Coefficient } \\
\text { (Standard Error) } \\
\text { [Marginal Effect] }\end{array}$ & $\begin{array}{c}\text { Model } 5 \\
\text { Coefficient } \\
\text { (Standard Error) } \\
\text { [Marginal Effect] }\end{array}$ \\
\hline $\begin{array}{l}\text { Parents' Relationship } \\
\text { Married at Time of Birth }\end{array}$ & $\begin{array}{l}-.492^{* * *} \\
(.130) \\
{[-.060]}\end{array}$ & $\begin{array}{l}-.508^{* * *} \\
(.133) \\
{[-.059]}\end{array}$ & $\begin{array}{c}-.502^{* * *} \\
(.126) \\
{[-.061]}\end{array}$ & & \\
\hline $\begin{array}{l}\text { Mother Knew Father }>=12 \text { Months } \\
\text { Prior to Conception }\end{array}$ & & & & $\begin{array}{l}.066 \\
(.114) \\
{[.009]}\end{array}$ & $\begin{array}{l}.038 \\
(.097) \\
{[.005]}\end{array}$ \\
\hline Married at Time of Conception & & & & $\begin{array}{l}-.323 \\
(.211) \\
{[-.038]}\end{array}$ & $\begin{array}{l}-.304 \\
(.202) \\
{[-.037]}\end{array}$ \\
\hline $\begin{array}{l}\text { States }^{+} \\
\text {California }\end{array}$ & & $\begin{array}{l}-.185 \\
(.261) \\
{[-.024]}\end{array}$ & & $\begin{array}{l}-.109 \\
(.262) \\
{[-.014]}\end{array}$ & \\
\hline Texas & & $\begin{array}{l}.053 \\
(.044) \\
{[-.007]}\end{array}$ & & $\begin{array}{l}-.005 \\
(.043) \\
{[-.001]}\end{array}$ & \\
\hline Maryland & & $\begin{array}{l}.010 \\
(.093) \\
{[.001]}\end{array}$ & & $\begin{array}{l}.044 \\
(.105) \\
{[.006]}\end{array}$ & \\
\hline Pennsylvania & & $\begin{array}{l}-.567^{* \star *} \\
(.150) \\
{[-.060]}\end{array}$ & & $\begin{array}{c}-.507^{\star \star *} \\
(.159) \\
{[-.053]}\end{array}$ & \\
\hline
\end{tabular}


Table 3a: Drug Use during Pregnancy - Cocaine Prices

Dependent Variable - Drug Use from Interview or Medical Records

\begin{tabular}{|c|c|c|c|c|c|}
\hline & $\begin{array}{c}\text { Model 1 } \\
\text { Coefficient } \\
\text { (Standard Error) } \\
\text { [Marginal Effect] }\end{array}$ & $\begin{array}{c}\text { Model 2 } \\
\text { Coefficient } \\
\text { (Standard Error) } \\
\text { [Marginal Effect] }\end{array}$ & $\begin{array}{c}\text { Model 3 } \\
\text { Coefficient } \\
\text { (Standard Error) } \\
\text { [Marginal Effect] }\end{array}$ & $\begin{array}{c}\text { Model 4 } \\
\text { Coefficient } \\
\text { (Standard Error) } \\
\text { [Marginal Effect] }\end{array}$ & $\begin{array}{c}\text { Model 5 } \\
\text { Coefficient } \\
\text { (Standard Error) } \\
\text { [Marginal Effect] }\end{array}$ \\
\hline $\begin{array}{c}\text { States (cont.) } \\
\text { Virginia }\end{array}$ & & $\begin{array}{c}-.298^{\star * *} \\
(.079) \\
{[-.034]}\end{array}$ & & $\begin{array}{l}-.261^{* *} \\
(.120) \\
{[-.029]}\end{array}$ & \\
\hline Florida & & $\begin{array}{c}-.678^{* * *} \\
(.036) \\
{[-.061]}\end{array}$ & & $\begin{array}{c}-.567^{* * *} \\
(.041) \\
{[-.052]}\end{array}$ & \\
\hline $\begin{array}{l}\text { City Characteristics } \\
\text { Median Yearly Family Income } \\
\text { (\$ Thousands) }\end{array}$ & & & $\begin{array}{l}-.000 \\
(.000) \\
{[-.000]}\end{array}$ & & $\begin{array}{l}-.000 \\
(.000) \\
{[-.000]}\end{array}$ \\
\hline $\begin{array}{l}\text { Drug Prices } \\
\text { Real (2000) Price of } 1 \text { Gram of Pure } \\
\text { Cocaine }\end{array}$ & $\begin{array}{c}-.103^{\star * *} \\
(.037) \\
{[-.015]}\end{array}$ & $\begin{array}{c}-.119^{\star * \star} \\
(.036) \\
{[-.017]}\end{array}$ & $\begin{array}{l}-.106^{* * *} \\
(.039) \\
{[-.015]}\end{array}$ & $\begin{array}{l}-.113^{* * *} \\
(.035) \\
{[-.015]}\end{array}$ & $\begin{array}{l}-.103^{* * *} \\
(.037) \\
{[-.014]}\end{array}$ \\
\hline Constant & $\begin{array}{l}-.453 \\
(.531)\end{array}$ & $\begin{array}{l}-.097 \\
(.704)\end{array}$ & $\begin{array}{l}-.098 \\
(.628)\end{array}$ & $\begin{array}{l}-.412 \\
(.835)\end{array}$ & $\begin{array}{l}-.382 \\
(.698)\end{array}$ \\
\hline Observations & 1748 & 1748 & 1748 & 1748 & 1748 \\
\hline
\end{tabular}

* significant at $10 \% ;{ }^{* *}$ significant at $5 \% ;{ }^{* * *}$ significant at $1 \%$

+ Massachusetts is the omitted State. 
Table 3b: Drug Use during Pregnancy - Heroin Prices

Dependent Variable - Drug Use from Interview or Medical Records

\begin{tabular}{|c|c|c|c|c|c|}
\hline & $\begin{array}{c}\text { Model 1 } \\
\text { Coefficient } \\
\text { (Standard Error) } \\
\text { [Marginal Effect] }\end{array}$ & $\begin{array}{c}\text { Model } 2 \\
\text { Coefficient } \\
\text { (Standard Error) } \\
\text { [Marginal Effect] }\end{array}$ & $\begin{array}{c}\text { Model 3 } \\
\text { Coefficient } \\
\text { (Standard Error) } \\
\text { [Marginal Effect] }\end{array}$ & $\begin{array}{c}\text { Model 4 } \\
\text { Coefficient } \\
\text { (Standard Error) } \\
\text { [Marginal Effect] }\end{array}$ & $\begin{array}{c}\text { Model 5 } \\
\text { Coefficient } \\
\text { (Standard Error) } \\
\text { [Marginal Effect] }\end{array}$ \\
\hline $\begin{array}{l}\text { Mother's Characteris } \\
\text { Age }\end{array}$ & $\begin{array}{l}.036 \\
(.034) \\
{[.005]}\end{array}$ & $\begin{array}{l}.032 \\
(.040) \\
{[.005]}\end{array}$ & $\begin{array}{l}.037 \\
(.033) \\
{[.005]}\end{array}$ & $\begin{array}{l}.023 \\
(.040) \\
{[.003]}\end{array}$ & $\begin{array}{l}.027 \\
(.033) \\
{[.004]}\end{array}$ \\
\hline Age Squared & $\begin{array}{l}-.000 \\
(.001) \\
{[-.000]}\end{array}$ & $\begin{array}{l}-.000 \\
(.001) \\
{[-.000]}\end{array}$ & $\begin{array}{l}-.000 \\
(.001) \\
{[-.000]}\end{array}$ & $\begin{array}{l}.000 \\
(.001) \\
{[.000]}\end{array}$ & $\begin{array}{l}.000 \\
(.001) \\
{[.000]}\end{array}$ \\
\hline High School Grad & $\begin{array}{l}-.244^{* *} \\
(.095) \\
{[-.033]}\end{array}$ & $\begin{array}{l}-.236^{* * *} \\
(.105) \\
{[-.031]}\end{array}$ & $\begin{array}{l}-.254^{* * *} \\
(.092) \\
{[-.034]}\end{array}$ & $\begin{array}{l}-.151 \\
(.119) \\
{[-.020]}\end{array}$ & $\begin{array}{l}-.171^{*} \\
(.103) \\
{[-.022]}\end{array}$ \\
\hline Some College & $\begin{array}{l}-.454^{* * *} \\
(.100) \\
{[-.055]}\end{array}$ & $\begin{array}{l}-.460^{* * *} \\
(.129) \\
{[-.055]}\end{array}$ & $\begin{array}{l}-.450^{* * *} \\
(.103) \\
{[-.054]}\end{array}$ & $\begin{array}{l}-.328^{* * *} \\
(.117) \\
{[-.039]}\end{array}$ & $\begin{array}{l}-.323^{* * *} \\
(.107) \\
{[-.039]}\end{array}$ \\
\hline College Grad & $\begin{array}{c}-1.021^{* * *} \\
(.155) \\
{[-.083]}\end{array}$ & $\begin{array}{c}-1.032^{* * *} \\
(.160) \\
{[-.082]}\end{array}$ & $\begin{array}{c}-1.034^{* * *} \\
(.152) \\
{[-.083]}\end{array}$ & $\begin{array}{c}-.920^{* * *} \\
(.232) \\
{[-.074]}\end{array}$ & $\begin{array}{c}-.929^{* * *} \\
(.215) \\
{[-.075]}\end{array}$ \\
\hline Medicaid & & & & $\begin{array}{l}.340^{* *} \\
(.148) \\
{[.043]}\end{array}$ & $\begin{array}{l}.334^{* *} \\
(.146) \\
{[.043]}\end{array}$ \\
\hline Black & $\begin{array}{l}.109 \\
(.106) \\
{[.016]}\end{array}$ & $\begin{array}{l}.104 \\
(.128) \\
{[.015]}\end{array}$ & $\begin{array}{l}.027 \\
(.089) \\
{[.004]}\end{array}$ & $\begin{array}{l}.111 \\
(.134) \\
{[.015]}\end{array}$ & $\begin{array}{l}.041 \\
(.089) \\
{[.006]}\end{array}$ \\
\hline Hispanic & $\begin{array}{l}-.449^{* * *} \\
(.082) \\
{[-.060]}\end{array}$ & $\begin{array}{l}-.484^{* * *} \\
(.103) \\
{[-.063]}\end{array}$ & $\begin{array}{l}-.412^{* * *} \\
(.086) \\
{[-.055]}\end{array}$ & $\begin{array}{l}-.486^{* * *} \\
(.110) \\
{[-.061]}\end{array}$ & $\begin{array}{l}-.421^{* * *} \\
(.105) \\
{[-.054]}\end{array}$ \\
\hline
\end{tabular}


Table 3b: Drug Use during Pregnancy - Heroin Prices

Dependent Variable - Drug Use from Interview or Medical Records

\begin{tabular}{|c|c|c|c|c|c|}
\hline & $\begin{array}{c}\text { Model 1 } \\
\text { Coefficient } \\
\text { (Standard Error) } \\
\text { [Marginal Effect] }\end{array}$ & $\begin{array}{c}\text { Model 2 } \\
\text { Coefficient } \\
\text { (Standard Error) } \\
\text { [Marginal Effect] }\end{array}$ & $\begin{array}{c}\text { Model } 3 \\
\text { Coefficient } \\
\text { (Standard Error) } \\
\text { [Marginal Effect] }\end{array}$ & $\begin{array}{c}\text { Model 4 } \\
\text { Coefficient } \\
\text { (Standard Error) } \\
\text { [Marginal Effect] }\end{array}$ & $\begin{array}{c}\text { Model 5 } \\
\text { Coefficient } \\
\text { (Standard Error) } \\
\text { [Marginal Effect] }\end{array}$ \\
\hline \multicolumn{6}{|l|}{ Mother's Characteristics (cont.) } \\
\hline $\begin{array}{l}\text { 'Other' Race } \\
\text { (Not White, Black, or Hispanic) }\end{array}$ & $\begin{array}{l}-.199 \\
(.335) \\
{[-.025]}\end{array}$ & $\begin{array}{l}-.260 \\
(.289) \\
{[-.031]}\end{array}$ & $\begin{array}{l}-.190 \\
(.322) \\
{[-.024]}\end{array}$ & $\begin{array}{l}-.220 \\
(.281) \\
{[-.026]}\end{array}$ & $\begin{array}{l}-.155 \\
(.310) \\
{[-.019]}\end{array}$ \\
\hline Immigrant & $\begin{array}{c}-1.020^{* * *} \\
(.094) \\
{[-.097]}\end{array}$ & $\begin{array}{c}-1.045^{\star * *} \\
(.182) \\
{[-.097]}\end{array}$ & $\begin{array}{c}-.937^{* * *} \\
(.149) \\
{[-.091]}\end{array}$ & $\begin{array}{c}-1.108^{* \star *} \\
(.196) \\
{[-.096]}\end{array}$ & $\begin{array}{c}-1.007^{* * *} \\
(.160) \\
{[-.091]}\end{array}$ \\
\hline First Birth & $\begin{array}{l}-.050 \\
(.098) \\
{[-.007]}\end{array}$ & $\begin{array}{l}-.032 \\
(.095) \\
{[-.004]}\end{array}$ & $\begin{array}{l}-.050 \\
(.098) \\
{[-.007]}\end{array}$ & $\begin{array}{l}.035 \\
(.107) \\
{[.005]}\end{array}$ & $\begin{array}{l}.019 \\
(.109) \\
{[.003]}\end{array}$ \\
\hline Number of Pregnancies & $\begin{array}{l}.112 \\
(.115) \\
{[.016]}\end{array}$ & $\begin{array}{c}.139 \\
(.118) \\
{[.019]}\end{array}$ & $\begin{array}{l}.093 \\
(.120) \\
{[.013]}\end{array}$ & $\begin{array}{l}.129 \\
(.133) \\
{[.017]}\end{array}$ & $\begin{array}{l}.088 \\
(.133) \\
{[.012]}\end{array}$ \\
\hline Lived with Both Parents at Age 15 & & & & $\begin{array}{l}-.016 \\
(.053) \\
{[-.002]}\end{array}$ & $\begin{array}{l}-.021 \\
(.056) \\
{[-.003]}\end{array}$ \\
\hline $\begin{array}{l}\text { Attended Religious Services Several } \\
\text { Times/Month }\end{array}$ & & & & $\begin{array}{c}-.224^{* * *} \\
(.087) \\
{[-.032]}\end{array}$ & $\begin{array}{c}-.243^{* * *} \\
(.082) \\
{[-.032]}\end{array}$ \\
\hline $\begin{array}{l}\text { Age Difference Between Father and } \\
\text { Mother }\end{array}$ & & & & $\begin{array}{l}.026^{* * *} \\
(.005) \\
{[.004]}\end{array}$ & $\begin{array}{l}.026^{* \star *} \\
(.005) \\
{[.004]}\end{array}$ \\
\hline $\begin{array}{l}\text { Father Characteristics } \\
\qquad \text { High School Grad }\end{array}$ & & & & $\begin{array}{l}-.245^{\star * *} \\
(.058) \\
{[-.035]}\end{array}$ & $\begin{array}{c}-.244^{* * *} \\
(.050) \\
{[-.035]}\end{array}$ \\
\hline
\end{tabular}


Table 3b: Drug Use during Pregnancy - Heroin Prices

Dependent Variable - Drug Use from Interview or Medical Records

\begin{tabular}{|c|c|c|c|c|c|}
\hline & $\begin{array}{c}\text { Model 1 } \\
\text { Coefficient } \\
\text { (Standard Error) } \\
\text { [Marginal Effect] }\end{array}$ & $\begin{array}{c}\text { Model } 2 \\
\text { Coefficient } \\
\text { (Standard Error) } \\
\text { [Marginal Effect] }\end{array}$ & $\begin{array}{c}\text { Model } 3 \\
\text { Coefficient } \\
\text { (Standard Error) } \\
\text { [Marginal Effect] }\end{array}$ & $\begin{array}{c}\text { Model } 4 \\
\text { Coefficient } \\
\text { (Standard Error) } \\
\text { [Marginal Effect] }\end{array}$ & $\begin{array}{c}\text { Model } 5 \\
\text { Coefficient } \\
\text { (Standard Error) } \\
\text { [Marginal Effect] }\end{array}$ \\
\hline $\begin{array}{l}\text { Parents' Relationship } \\
\text { Married at Time of Birth }\end{array}$ & $\begin{array}{l}-.509^{* * *} \\
(.134) \\
{[-.061]}\end{array}$ & $\begin{array}{c}-.512^{* * *} \\
(.132) \\
{[-.061]}\end{array}$ & $\begin{array}{c}-.530^{\star * *} \\
(.131) \\
{[-.063]}\end{array}$ & & \\
\hline $\begin{array}{l}\text { Mother Knew Father }>=12 \text { Months } \\
\text { Prior to Conception }\end{array}$ & & & & $\begin{array}{l}.058 \\
(.112) \\
{[.008]}\end{array}$ & $\begin{array}{l}.052 \\
(.106) \\
{[.007]}\end{array}$ \\
\hline Married at Time of Conception & & & & $\begin{array}{l}-.320 \\
(.215) \\
{[-.039]}\end{array}$ & $\begin{array}{l}-.329 \\
(.206) \\
{[-.040]}\end{array}$ \\
\hline $\begin{array}{l}\text { States } \\
\qquad \text { California }\end{array}$ & & $\begin{array}{c}.673 \\
(1.028) \\
{[.118]}\end{array}$ & & $\begin{array}{l}.675 \\
(.987) \\
{[.115]}\end{array}$ & \\
\hline Texas & & $\begin{array}{l}.272 \\
(.646) \\
{[.042]}\end{array}$ & & $\begin{array}{l}.285 \\
(.630) \\
{[.042]}\end{array}$ & \\
\hline Maryland & & $\begin{array}{l}.427 \\
(.932) \\
{[.074]}\end{array}$ & & $\begin{array}{l}.414 \\
(.888) \\
{[.069]}\end{array}$ & \\
\hline Pennsylvania & & $\begin{array}{l}-.057 \\
(.405) \\
{[-.008]}\end{array}$ & & $\begin{array}{l}-.034 \\
(.380) \\
{[-.005]}\end{array}$ & \\
\hline
\end{tabular}


Table 3b: Drug Use during Pregnancy - Heroin Prices

Dependent Variable - Drug Use from Interview or Medical Records

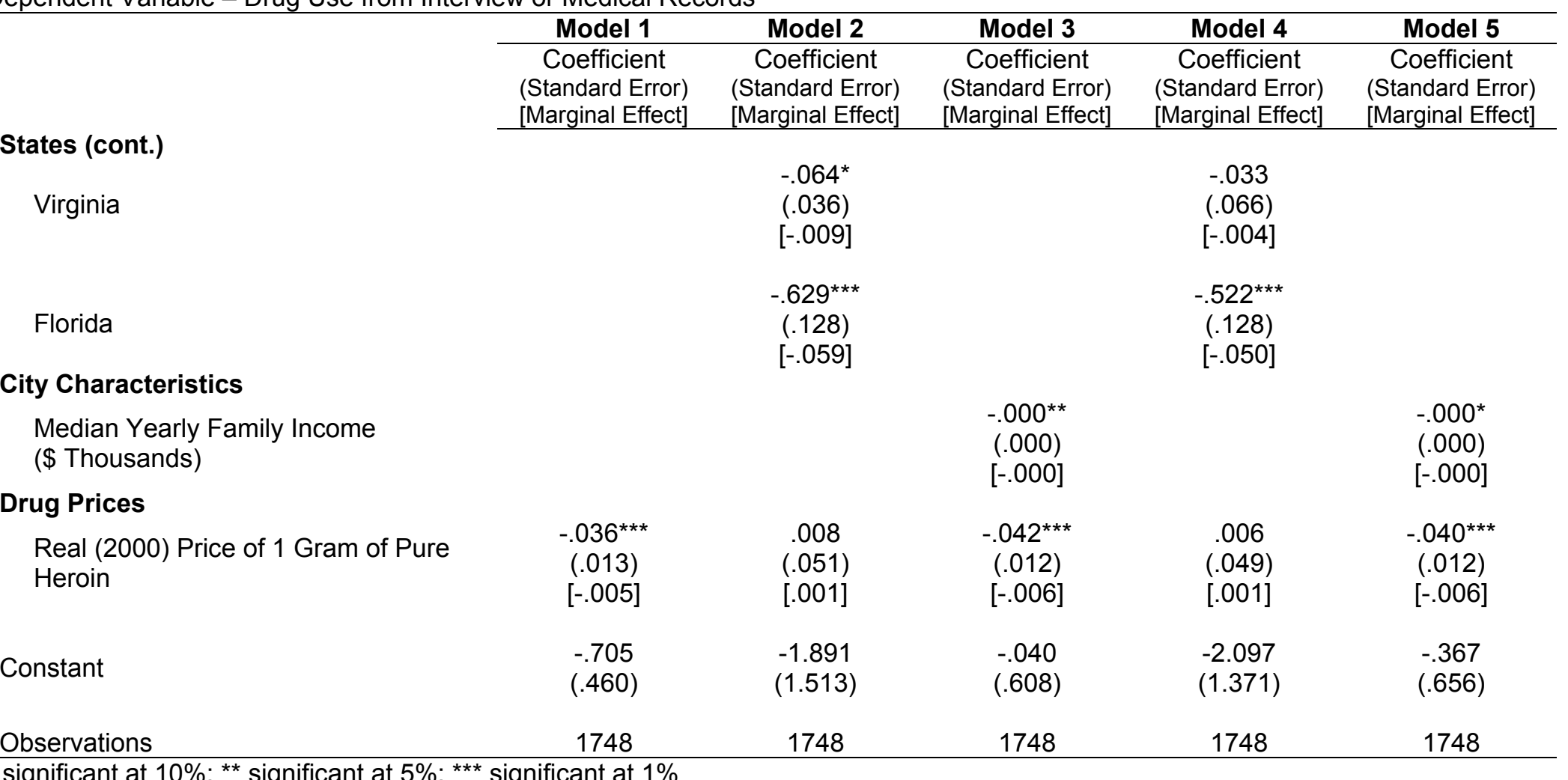

${ }^{*}$ significant at $10 \% ;{ }^{* *}$ significant at $5 \% ;{ }^{* * *}$ significant at $1 \%$ 
Table 4a: Drug Use During Pregnancy - Cocaine Prices, Using Alternative Measures of Drug Use

\begin{tabular}{|c|c|c|c|c|c|c|}
\hline & \multicolumn{2}{|c|}{ Interview } & \multicolumn{2}{|c|}{ Medical Records } & \multicolumn{2}{|c|}{ Interview or Medical Records } \\
\hline & $\begin{array}{c}\text { Coefficient } \\
\text { (Standard Deviation) }\end{array}$ & Marginal Effect & $\begin{array}{c}\text { Coefficient } \\
\text { (Standard Deviation) }\end{array}$ & Marginal Effect & $\begin{array}{c}\text { Coefficient } \\
\text { (Standard Deviation) }\end{array}$ & Marginal Effect \\
\hline $\begin{array}{l}\text { Mother's Characteristics } \\
\text { Age }\end{array}$ & $\begin{array}{l}0.055 \\
(0.059)\end{array}$ & 0.004 & $\begin{array}{c}0.046 \\
(0.032)\end{array}$ & 0.006 & $\begin{array}{c}0.022 \\
(0.030)\end{array}$ & 0.003 \\
\hline Age Squared & $\begin{array}{l}-0.000 \\
(0.001)\end{array}$ & -0.000 & $\begin{array}{l}-0.000 \\
(0.001)\end{array}$ & -0.000 & $\begin{array}{c}0.000 \\
(0.001)\end{array}$ & 0.000 \\
\hline High School Grad & $\begin{array}{c}-0.430 * * * \\
(0.099)\end{array}$ & -0.024 & $\begin{array}{l}-0.169 \\
(0.103)\end{array}$ & -0.021 & $\begin{array}{l}-0.158 \\
(0.105)\end{array}$ & -0.021 \\
\hline Some College & $\begin{array}{l}-0.542^{* * *} \\
(0.114)\end{array}$ & -0.028 & $\begin{array}{l}-0.332^{* *} \\
(0.138)\end{array}$ & -0.038 & $\begin{array}{c}-0.308^{* * *} \\
(0.111)\end{array}$ & -0.038 \\
\hline College Grad & $\begin{array}{l}-1.035^{\star * *} \\
(0.242)\end{array}$ & -0.034 & $\begin{array}{l}-0.837^{* * *} \\
(0.224)\end{array}$ & -0.067 & $\begin{array}{c}-0.904^{* * *} \\
(0.218)\end{array}$ & -0.074 \\
\hline Medicaid & $\begin{array}{c}0.111 \\
(0.163)\end{array}$ & 0.007 & $\begin{array}{l}0.371^{* *} \\
(0.150)\end{array}$ & 0.045 & $\begin{array}{l}0.327^{* *} \\
(0.148)\end{array}$ & 0.042 \\
\hline Black & $\begin{array}{l}-0.031 \\
(0.173)\end{array}$ & -0.002 & $\begin{array}{c}0.061 \\
(0.166)\end{array}$ & 0.008 & $\begin{array}{c}0.037 \\
(0.109)\end{array}$ & 0.005 \\
\hline Hispanic & $\begin{array}{l}-0.468^{* * *} \\
(0.170)\end{array}$ & -0.028 & $\begin{array}{l}-0.377^{* * *} \\
(0.122)\end{array}$ & -0.046 & $\begin{array}{l}-0.434^{* * *} \\
(0.102)\end{array}$ & -0.056 \\
\hline $\begin{array}{l}\text { 'Other' Race } \\
\text { (Not White, Black or Hispanic) }\end{array}$ & $\begin{array}{c}0.022 \\
(0.260)\end{array}$ & 0.002 & $\begin{array}{l}-0.160 \\
(0.282)\end{array}$ & -0.019 & $\begin{array}{l}-0.238 \\
(0.279)\end{array}$ & -0.028 \\
\hline Immigrant & $\begin{array}{c}-0.783^{* * *} \\
(0.069)\end{array}$ & -0.034 & $\begin{array}{c}-1.059^{* * *} \\
(0.201)\end{array}$ & -0.089 & $\begin{array}{c}-1.032^{* * *} \\
(0.196)\end{array}$ & -0.093 \\
\hline
\end{tabular}


Table 4a: Drug Use During Pregnancy - Cocaine Prices, Using Alternative Measures of Drug Use

\begin{tabular}{|c|c|c|c|c|c|c|}
\hline \multirow{3}{*}{$\begin{array}{l}\text { Mother's Characteristic's (cont.) } \\
\text { Lived with Both Parents at Age } 15\end{array}$} & \multicolumn{2}{|c|}{ Interview } & \multicolumn{2}{|c|}{ Medical Records } & \multicolumn{2}{|c|}{ Interview or Medical Records } \\
\hline & $\begin{array}{c}\text { Coefficient } \\
\text { (Standard Deviation) }\end{array}$ & Marginal Effect & $\begin{array}{c}\text { Coefficient } \\
\text { (Standard Deviation) }\end{array}$ & Marginal Effect & $\begin{array}{c}\text { Coefficient } \\
\text { (Standard Deviation) }\end{array}$ & Marginal Effect \\
\hline & $\begin{array}{l}-0.124^{* *} \\
(0.050)\end{array}$ & -0.008 & $\begin{array}{l}-0.011 \\
(0.059)\end{array}$ & -0.001 & $\begin{array}{l}-0.016 \\
(0.054)\end{array}$ & -0.002 \\
\hline $\begin{array}{l}\text { Attended Religious Services } \\
\text { Several Times/Month }\end{array}$ & $\begin{array}{c}-0.270^{* * *} \\
(0.093)\end{array}$ & -0.017 & $\begin{array}{l}-0.249^{* *} \\
(0.110)\end{array}$ & -0.031 & $\begin{array}{c}-0.269^{* * *} \\
(0.091)\end{array}$ & -0.036 \\
\hline First Birth & $\begin{array}{l}-0.054 \\
(0.125)\end{array}$ & -0.003 & $\begin{array}{l}0.037 \\
(0.100)\end{array}$ & 0.005 & $\begin{array}{l}0.003 \\
(0.102)\end{array}$ & 0.000 \\
\hline Number of Pregnancies & $\begin{array}{c}0.066 \\
(0.208)\end{array}$ & 0.004 & $\begin{array}{c}0.112 \\
(0.136)\end{array}$ & 0.014 & $\begin{array}{c}0.075 \\
(0.123)\end{array}$ & 0.010 \\
\hline $\begin{array}{l}\text { Father's Characteristics } \\
\text { High School Grad }\end{array}$ & $\begin{array}{l}-0.235^{\star *} \\
(0.093)\end{array}$ & -0.016 & $\begin{array}{c}-0.311^{* * *} \\
(0.075)\end{array}$ & -0.043 & $\begin{array}{c}-0.263^{* * *} \\
(0.053)\end{array}$ & -0.038 \\
\hline $\begin{array}{l}\text { Mother Knew Father }>=12 \text { Months } \\
\text { Prior to Conception }\end{array}$ & $\begin{array}{l}-0.058 \\
(0.069)\end{array}$ & -0.004 & $\begin{array}{l}0.036 \\
(0.095)\end{array}$ & 0.005 & $\begin{array}{c}0.038 \\
(0.097)\end{array}$ & 0.005 \\
\hline $\begin{array}{l}\text { Age Difference Between Father } \\
\text { and Mother }\end{array}$ & $\begin{array}{c}0.040^{* * *} \\
(0.007)\end{array}$ & 0.003 & $\begin{array}{c}0.027^{* * *} \\
(0.004)\end{array}$ & 0.003 & $\begin{array}{c}0.025^{* * *} \\
(0.005)\end{array}$ & 0.003 \\
\hline Married at Time of Conception & $\begin{array}{c}-0.576^{* *} \\
(0.250)\end{array}$ & -0.029 & $\begin{array}{l}-0.291 \\
(0.210)\end{array}$ & -0.034 & $\begin{array}{l}-0.304 \\
(0.202)\end{array}$ & -0.037 \\
\hline $\begin{array}{l}\text { City Characteristics } \\
\text { Median Yearly Family Income } \\
\text { (\$ Thousands) }\end{array}$ & $\begin{array}{l}-0.000 \\
(0.000)\end{array}$ & -0.000 & $\begin{array}{l}-0.000 \\
(0.000)\end{array}$ & -0.000 & $\begin{array}{l}-0.000 \\
(0.000)\end{array}$ & -0.000 \\
\hline $\begin{array}{l}\text { Real (2000) Price of } 1 \text { Gram of } \\
\text { Pure Cocaine }\end{array}$ & $\begin{array}{c}-0.074^{* *} \\
(0.036)\end{array}$ & -0.005 & $\begin{array}{c}-0.106^{* * *} \\
(0.037)\end{array}$ & -0.014 & $\begin{array}{l}-0.103^{* * *} \\
(0.037)\end{array}$ & -0.014 \\
\hline Constant & $\begin{array}{l}-1.051 \\
(1.108)\end{array}$ & & $\begin{array}{l}-0.840 \\
(0.630)\end{array}$ & & $\begin{array}{l}-0.382 \\
(0.698)\end{array}$ & \\
\hline Observations & 1748 & & 1748 & & 1748 & \\
\hline
\end{tabular}


Table 4b: Drug Use During Pregnancy - Heroin Prices, Using Alternative Measures of Drug Use

\begin{tabular}{|c|c|c|c|c|c|c|}
\hline \multirow{2}{*}{ Mother's Characteristics } & \multicolumn{2}{|c|}{ Interview } & \multicolumn{2}{|c|}{ Medical Records } & \multicolumn{2}{|c|}{ Interview or Medical Records } \\
\hline & $\begin{array}{c}\text { Coefficient } \\
\text { (Standard Deviation) }\end{array}$ & Marginal Effect & $\begin{array}{c}\text { Coefficient } \\
\text { (Standard Deviation) }\end{array}$ & Marginal Effect & $\begin{array}{c}\text { Coefficient } \\
\text { (Standard Deviation) }\end{array}$ & Marginal Effect \\
\hline $\begin{array}{l}\text { Mother's Characteris } \\
\text { Age }\end{array}$ & $\begin{array}{c}0.057 \\
(0.059)\end{array}$ & 0.004 & $\begin{array}{c}0.051 \\
(0.035)\end{array}$ & 0.007 & $\begin{array}{c}0.027 \\
(0.033)\end{array}$ & 0.004 \\
\hline Age Squared & $\begin{array}{l}-0.000 \\
(0.001)\end{array}$ & -0.000 & $\begin{array}{l}-0.000 \\
(0.001)\end{array}$ & -0.000 & $\begin{array}{c}0.000 \\
(0.001)\end{array}$ & 0.000 \\
\hline High School Grad & $\begin{array}{c}-0.436^{* * *} \\
(0.097)\end{array}$ & -0.025 & $\begin{array}{l}-0.184^{*} \\
(0.103)\end{array}$ & -0.023 & $\begin{array}{l}-0.171^{*} \\
(0.103)\end{array}$ & -0.022 \\
\hline Some College & $\begin{array}{c}-0.553^{* * *} \\
(0.113)\end{array}$ & -0.028 & $\begin{array}{c}-0.345^{\star * *} \\
(0.134)\end{array}$ & -0.039 & $\begin{array}{c}-0.323^{* * *} \\
(0.107)\end{array}$ & -0.039 \\
\hline College Grad & $\begin{array}{c}-1.052^{* * *} \\
(0.250)\end{array}$ & -0.034 & $\begin{array}{c}-0.869^{* * *} \\
(0.225)\end{array}$ & -0.067 & $\begin{array}{c}-0.929 * * * \\
(0.215)\end{array}$ & -0.075 \\
\hline Medicaid & $\begin{array}{c}0.118 \\
(0.158)\end{array}$ & 0.008 & $\begin{array}{l}0.379 * * \\
(0.152)\end{array}$ & 0.045 & $\begin{array}{l}0.334^{* *} \\
(0.146)\end{array}$ & 0.043 \\
\hline Black & $\begin{array}{l}-0.016 \\
(0.167)\end{array}$ & -0.001 & $\begin{array}{c}0.049 \\
(0.131)\end{array}$ & 0.006 & $\begin{array}{c}0.041 \\
(0.089)\end{array}$ & 0.006 \\
\hline Hispanic & $\begin{array}{c}-0.452^{* * *} \\
(0.156)\end{array}$ & -0.027 & $\begin{array}{c}-0.376^{\star * *} \\
(0.139)\end{array}$ & -0.045 & $\begin{array}{c}-0.421^{* * *} \\
(0.105)\end{array}$ & -0.054 \\
\hline 'Other' Race & $\begin{array}{c}0.089 \\
(0.273)\end{array}$ & 0.006 & $\begin{array}{l}-0.086 \\
(0.313)\end{array}$ & -0.011 & $\begin{array}{l}-0.155 \\
(0.310)\end{array}$ & -0.019 \\
\hline Immigrant & $\begin{array}{c}-0.756^{* * *} \\
(0.084)\end{array}$ & -0.034 & $\begin{array}{c}-1.047^{* * *} \\
(0.168)\end{array}$ & -0.087 & $\begin{array}{c}-1.007^{* * *} \\
(0.160)\end{array}$ & -0.091 \\
\hline
\end{tabular}

Continued on next page 
Table 4b: Drug Use During Pregnancy - Probit Results, Using Alternative Measures of Drug Use

\begin{tabular}{|c|c|c|c|c|c|c|}
\hline \multirow{2}{*}{ Mother's Characteristic's (cont.) } & \multicolumn{2}{|c|}{ Interview } & \multicolumn{2}{|c|}{ Medical Records } & \multicolumn{2}{|c|}{ Interview or Medical Records } \\
\hline & $\begin{array}{c}\text { Coefficient } \\
\text { (Standard Deviation) }\end{array}$ & Marginal Effect & $\begin{array}{c}\text { Coefficient } \\
\text { (Standard Deviation) }\end{array}$ & Marginal Effect & $\begin{array}{c}\text { Coefficient } \\
\text { (Standard Deviation) }\end{array}$ & Marginal Effect \\
\hline $\begin{array}{l}\text { Mother's Characteristic's (cont.) } \\
\text { Lived with Both Parents at Age } 15\end{array}$ & $\begin{array}{l}-0.125^{\star *} \\
(0.052)\end{array}$ & -0.008 & $\begin{array}{l}-0.014 \\
(0.058)\end{array}$ & -0.002 & $\begin{array}{l}-0.021 \\
(0.056)\end{array}$ & -0.003 \\
\hline $\begin{array}{l}\text { Attended Religious Services } \\
\text { Several Times/Month }\end{array}$ & $\begin{array}{c}-0.242^{\star * *} \\
(0.092)\end{array}$ & -0.015 & $\begin{array}{c}-0.218^{* *} \\
(0.099)\end{array}$ & -0.027 & $\begin{array}{c}-0.243^{* * *} \\
(0.082)\end{array}$ & -0.032 \\
\hline First Birth & $\begin{array}{l}-0.039 \\
(0.129)\end{array}$ & -0.003 & $\begin{array}{c}0.052 \\
(0.109)\end{array}$ & 0.007 & $\begin{array}{c}0.019 \\
(0.109)\end{array}$ & 0.003 \\
\hline Number of Pregnancies & $\begin{array}{c}0.086 \\
(0.215)\end{array}$ & 0.005 & $\begin{array}{c}0.122 \\
(0.146)\end{array}$ & 0.015 & $\begin{array}{c}0.088 \\
(0.133)\end{array}$ & 0.012 \\
\hline $\begin{array}{l}\text { Father's Characteristics } \\
\text { High School Grad }\end{array}$ & $\begin{array}{c}-0.218^{* *} \\
(0.098)\end{array}$ & -0.015 & $\begin{array}{l}-0.292^{* * *} \\
(0.074)\end{array}$ & -0.040 & $\begin{array}{l}-0.244^{* * *} \\
(0.050)\end{array}$ & -0.035 \\
\hline $\begin{array}{l}\text { Parent's Relationship } \\
\text { Mother Knew Father }>=12 \text { Months } \\
\text { Prior to Conception }\end{array}$ & $\begin{array}{l}-0.050 \\
(0.076)\end{array}$ & -0.003 & $\begin{array}{c}0.052 \\
(0.107)\end{array}$ & 0.007 & $\begin{array}{c}0.052 \\
(0.106)\end{array}$ & 0.007 \\
\hline Age Difference Between Father & $\begin{array}{c}0.041^{* * *} \\
(0.008)\end{array}$ & 0.003 & $\begin{array}{c}0.028^{* * *} \\
(0.004)\end{array}$ & 0.004 & $\begin{array}{c}0.026^{* * *} \\
(0.005)\end{array}$ & 0.004 \\
\hline Married at Time of Conception & $\begin{array}{c}-0.587^{* *} \\
(0.248)\end{array}$ & -0.030 & $\begin{array}{l}-0.317 \\
(0.215)\end{array}$ & -0.036 & $\begin{array}{l}-0.329 \\
(0.206)\end{array}$ & -0.040 \\
\hline $\begin{array}{l}\text { City Characteristics } \\
\text { Median Yearly Family Income } \\
\text { (\$ Thousands) }\end{array}$ & $\begin{array}{c}-0.000^{* *} \\
(0.000)\end{array}$ & -0.000 & $\begin{array}{l}-0.000 \\
(0.000)\end{array}$ & -0.000 & $\begin{array}{l}-0.000^{*} \\
(0.000)\end{array}$ & -0.000 \\
\hline $\begin{array}{l}\text { Drug Price } \\
\text { Real }(2000) \text { Price of } 1 \text { Gram of } \\
\text { Pure Heroin < } 40 \text { grams }\end{array}$ & $\begin{array}{l}-0.024^{*} \\
(0.014)\end{array}$ & -0.002 & $\begin{array}{l}-0.044^{* * *} \\
(0.012)\end{array}$ & -0.006 & $\begin{array}{l}-0.040^{* * *} \\
(0.012)\end{array}$ & -0.006 \\
\hline $\begin{array}{l}\text { Constant } \\
\text { Observations }\end{array}$ & $\begin{array}{c}-1.167 \\
(1.002) \\
1748\end{array}$ & & $\begin{array}{l}-0.720 \\
(0.708) \\
1748\end{array}$ & & $\begin{array}{l}-0.367 \\
(0.656) \\
1748\end{array}$ & \\
\hline
\end{tabular}

${ }^{*}$ significant at $10 \%$; ${ }^{* *}$ significant at $5 \%$; ${ }^{* * *}$ significant at $1 \%$ 


\section{Table 5}

\section{Elasticities of Prenatal Drug Use with Respect to Drug Prices}

\begin{tabular}{lccc}
\hline & Interview Report & Medical Records & Interview or Records \\
\cline { 2 - 4 } Cocaine & -.77 & -1.13 to -1.37 & -1.07 to -1.30 \\
Heroin & .75 to -.75 & 0 to -1.18 & 0.19 to -1.11 \\
\hline
\end{tabular}

